\title{
On the enigmatic Sinonemestrius Hong \& Wang, 1990, with description of a new species based on a complete fossil fly (Diptera, Brachycera, Tabanomorpha, Heterostomidae)
}

\author{
Junfeng Zhang ${ }^{1,2}$ \\ 1 College of Palaeontology, Shenyang Normal University, Shenyang, 110034, P. R. China \\ 2 Nanjing Institute of Geology and Palaeontology, Chinese Academy of Sciences, Nanjing 210008, P. R. China
}

http://zoobank.org/7380CB6B-A81C-4BF3-B141-0A3BBB7C59B5

Corresponding author: Junfeng Zhang (jfzhang@nigpas.ac.cn)

Received 10 January 2017

Accepted 3 April 2017

Published 7 April 2017

Academic editor:

Sonja Wedmann

\section{Key Words}

\section{Diptera}

Tabanomorpha

Sinonemestrius

new species

Cretaceous

Laiyang Formation

China

\begin{abstract}
A new species of Sinonemestrius Hong \& Wang, 1990 is described and illustrated based on a complete compression fossil of the fly. Currently placed in Rhagionemestriidae or Xylophagidae, the present study concludes that the morphology of the new find indicates that Sinonemestrius is a heterostomid genus within Tabanomorpha. The placement of Ahirmoneura neimengguensis K-y Zhang et al., 2008 is reassessed. It demonstrates close similarities in body structure and wing venation to those of Sinonemestrius, and can be provisionally transferred from Nemestrinidae to Heterostomidae: Sinonemestriinae.
\end{abstract}

\section{Introduction}

The Jehol biota (sensu lato) constitutes a suite of fossil plants and animals that lived during the Early Cretaceous in eastern- and north-eastern Asia (J-f Zhang 1992). As in the Lower Cretaceous Yixian Formation in Beipiao City of Liaoning Province, China (Ren and Guo 1995, Ren 1998), the order Diptera (true flies) is also well represented in the Lower Cretaceous of the Laiyang Formation in Laiyang City, Shandong Province, China. The suborder Brachycera is abundant. In the author's collection - about one half of the Diptera found is composed of Eremochaetidae (eremochaetid flies), Xylophagidae (awl-flies), Stratiomyidae (soldier flies), Nemestrinidae (tangle-veined flies), Tabanidae (horseflies), Athericidae (water snipe-flies), Rhagionidae (snipe flies), Empidi- dae (dance flies), Protapioceridae (protapiocerid flies), Platypezidae (flat-footed flies) and Ironomyiidae (ironic flies), etc. Among them, only a few taxa have been described (J-f Zhang 1987, 2012, 2014, 2015, Hong and Wang 1988, 1990, J-f Zhang et al. 1993).

A rare and unusual nemestrinid-like brachyceran wing from the Laiyang Formation in the vicinity of Tuanwang Village, Laiyang, Shandong, China was described by Hong and Wang (1990) and named Sinonemestrius tuanwangensis Hong \& Wang, 1990. The taxonomy and systematics of this enigmatic form have been much debated. It has a history of controversial taxonomy that has placed this nemestrinid taxon in up to four separate families (Hong and Wang 1990, Nagatomi and Yang 1998, Jarzembowski and Mostovski 2000, Mostovski and MartínezDelclòs 2000, Nel 2010, Grimaldi 2016). This problem 
is resolved here based on a new, complete compression of a sinonemestriid fly originating from the same fossil locality (Laiyang Formation in the vicinity of Tuanwang Village). In addition, the placement of another nemestrinid-like brachyceran, Ahirmoneura neimengguensis $\mathrm{K}$-y Zhang et al., 2008, is reassessed. It could be related to Heterostomidae:Sinonemestriinae as it demonstrates close similarities in body structure and wing venation to those of Sinonemestrius Hong \& Wang, 1990 rather than tangle-veined flies (see Remarks in Taxonomy below).

\section{Material and methods}

Material. The holotype of a shale fossil compression of a male sinonemestriid fly described herein is deposited in the collections of the Nanjing Institute of Geology and Palaeontology (NIGP), the Chinese Academy of Sciences, no. NIGP L91803. The fly-bearing sedimentary rocks of the Laiyang Formation are located near the village of Tuanwang, Laiyang City, Shandong Province, China.

Illustrations. Specimen descriptions, photomicrographs and line drawings were done with the application of glycerol to the surface of the specimens. The line drawings were produced with the aid of a camera lucida and the digital photomicrographs were taken using a stereomicroscope (Leica M205C).

Wing venation terminology here follows Wootton and Ennos (1989) and Shcherbakov et al. (1995). The cell traditionally named the anal cell is here considered to be the cubital cell. The following standard abbreviations are used: Sc, subcosta; R1, first radius; R2+3, second and third radius; $\mathrm{R} 4$, fourth radius; $\mathrm{R} 4+5$, fourth and fifth radius; bR4 4 , basal section of $\mathrm{R} 4+5$; $\mathrm{dR} 4+5$, distal section of R4+5; R5, fifth radius; Rs, radial sector; M1, first media, M2, second media; M3, third media, M4, fourth media; $\mathrm{CuA}$, cubitus anterior; $\mathrm{CuP}$, cubitus posterior; $\mathrm{r}-\mathrm{m}$, crossvein between radius and media; $\mathrm{m}-\mathrm{m}$, crossvein between media; $\mathrm{m}-\mathrm{cu}$, crossvein between media and cubitus; bm, basal cell of media; br, basal cell of radius; cu, cubital cell; dc, discal cell.

Colour described here refers to that of the fossil, where patterning is preserved, not the hue of the live fly.

\section{Taxonomy}

Heterostomidae Nagatomi, 1977

Sinonemestriinae Nagatomi \& Yang, 1998, stat. nov.

Sinonemestrius Hong \& Wang, 1990

Type-species. Sinonemestrius tuanwangensis Hong \& Wang, 1990

Included species. Sinonemestrius akirai Jarzembowski \& Mostovski, 2000 and Sinonemestrius completus sp. n., besides the type species Sinonemestrius tuanwangensis Hong \& Wang, 1990.
Diagnosis. Medium-sized flies with robust build; body covered with dense hairs but devoid of setae; head moderately large, semiglobose, shorter and narrower than thorax, comprised mostly of the eyes; eyes holoptic in male, hind margin with emargination; antenna short, corneous, with eight-segmented flagellum, first flagellomere swollen, stylus (or arista) absent; wing membrane with markings; R1 relatively short; R2+3 curved, relatively short, ending at, or near to, R1 tip; R4 usually sigmoidal; R5 nearly straight, aligned with stem of R4+5; crossvein $\mathrm{r}-\mathrm{m}$ present; R5 or M1 ending at wing tip; M2 ending behind wing tip; cell cu (traditionally anal cell) open; metatibia with two very short spurs; empodium present.

Remarks. The original generic diagnosis was defined based on wing impressions (Hong and Wang 1990, Jarzembowski and Mostovski 2000). A revised and supplemented diagnosis including some critical structures of the body is proposed here based on a complete compression fossil of the fly.

Based on a single impression fossil of a nemestrinid-like fly from the Jurassic of the Daohugou biota in the vicinity of Daohugou Village, Wuhua Township, Ningcheng County, Inner Mongolia, China, K-y Zhang et al. (2008) erected a new genus Ahirmoneura (type species: Ahirmoneura neimengguensis K-y Zhang et al., 2008). They classified this genus in Nemestrinidae. It certainly resembles representatives of the extinct nemestrinid subfamily Archinemestriinae and even some living tangle-veined flies in that R4, R5, M1 and M2 end near to the wing tip. Nevertheless, the clearly short R1 and the absence of the so-called diagonal vein exclude this genus from the Nemestrinidae. In many features (including body structures and wing venation), Ahirmoneura resembles Sinonemestrius (lack of setae on the body; hemispherical head; elongate-ovate abdomen covered with hairs; very short R1; R4, R5, M1 and M2 ending near to wing tip; and the so-called diagonal vein absent). It should be noted that the wing venation of Ahirmoneura neimengguensis demonstrates very close similarities to that of Sinonemestrius akirai (Figs 3C, D). The former species differs from the latter one only by the longer, straight $\mathrm{R} 2+3$, which ends at $\mathrm{C}$ far apart from the end of R1, M2 (instead of M1) ends just at the wing tip and $\mathrm{r}-\mathrm{m}$ meets the anterior margin of the discal cell near to its base. Unfortunately, the crucial structure of the antenna of Ahirmoneura neimengguensis is unknown. Until a new find (including antenna) of this species is available, Ahirmoneura can only be provisionally assigned to Heterostomidae: Sinonemestriinae.

\section{Sinonemestrius completus sp. $\mathbf{n}$.}

http://zoobank.org/EC9ED5D1-18AF-4A69-9CF0-47E5A17709CB Figs $1-3$

Diagnosis. Similar to Sinonemestrius tuanwangensis, but $\mathrm{R} 2+3$ smoothly curved downwards and parallel to R1, ending at $\mathrm{C}$ instead of $\mathrm{R} 1$ end; fork of $\mathrm{R} 4+5$ distinctly distad 

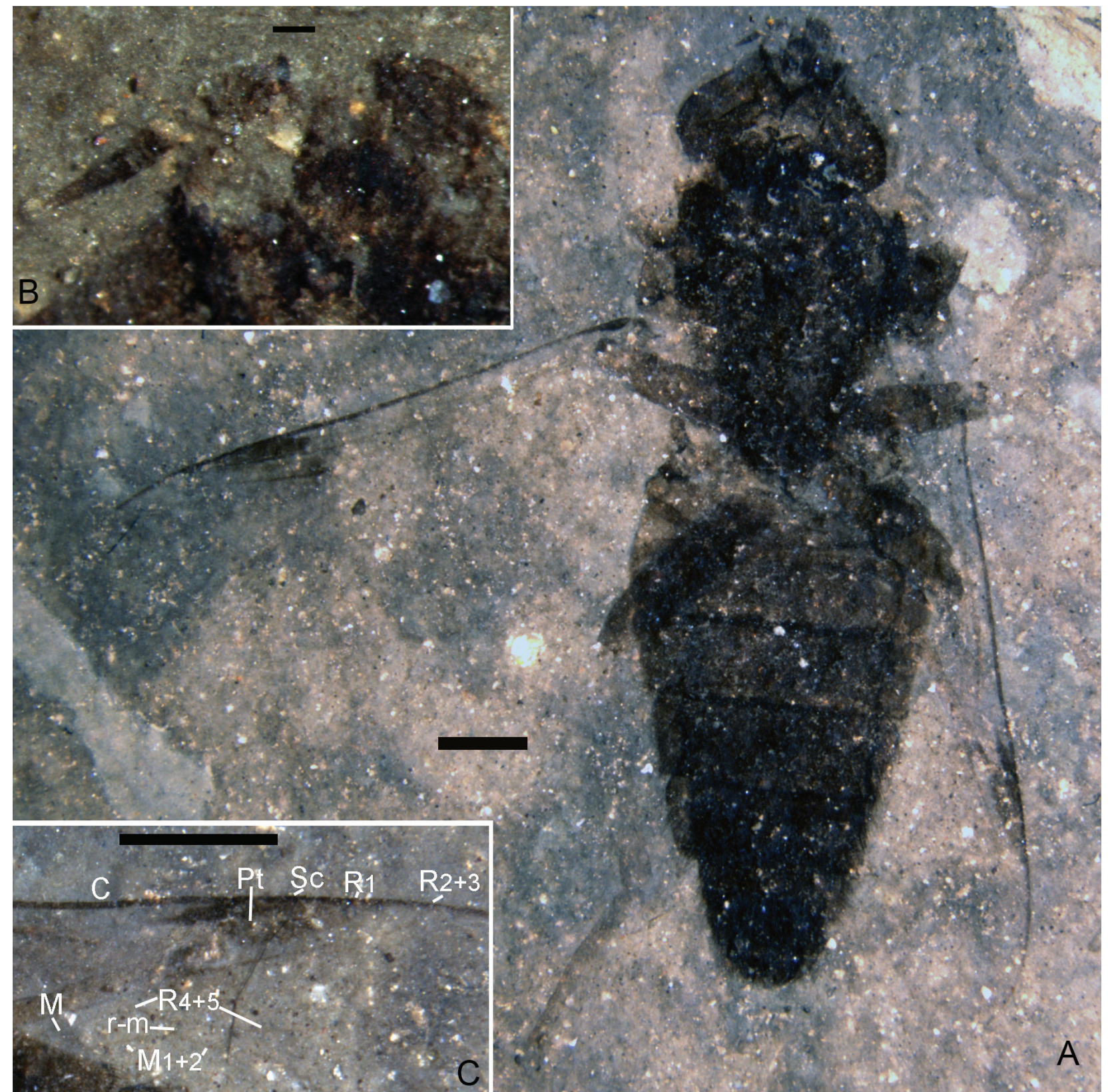

Figure 1. Sinonemestrius completus sp. n., no. NIGP L91803, holotype, photographs, male, dorsal view. A habitus, B antenna, C enlarged portions of right wing. Scale bars: $1 \mathrm{~mm}(\mathbf{A}, \mathbf{C})$ and $0.1 \mathrm{~mm}(\mathbf{B})$.

to fork of $\mathrm{M} 1+2$; crossvein $\mathrm{r}-\mathrm{m}$ meeting anterior margin of discal cell basad to its midlength; wing membrane with few markings (only limited to "Pt" and below it).

Description. Male medium-sized flies. Female unknown. Head moderately large, semiglobose, slightly narrower, but distinctly shorter, than thorax; vertex plus frons more or less flattened; eyes large, holoptic, covering almost entire head; antenna shorter than head, scape subquadrate, slightly wider than long, pedicel much shorter, less than one half of scape length, more than twice wider than long, first flagellomere extremely swollen, nearly pyriform, much longer and wider than scape and pedicel combined, less than twice as long as wide, other flagellomeres gradually tapering apically, about three times as long as first flagellomere (Figs 1B, 2B).
Thorax subovate, mesoscutum longer than wide, slightly wider than head; scutellum small, rounded apically, distinctly wider than long; wing nearly three times as long as wide; $\mathrm{C}$ thickened but thinned just at wing tip; R1 slightly curved smoothly, about three-fourths of wing length; Rs arising from $\mathrm{R}$ more or less late, about at one-third of wing length; $\mathrm{R} 2+3$ parallel to $\mathrm{R} 1$, ending at C; "Pt" well developed, another brown marking between R1 and R2+3 below base of "Pt" present (Figs 1A, C, 2C); Rs stem shorter than bR4+5, bR $4+5$ shorter than $\mathrm{dR} 4+5$, fork of $\mathrm{R} 4+5$ clearly distad to level of fork of $\mathrm{M} 1+2$; r-m meeting anterior margin of discal cell basad to its midlength, bM1+2 about one half of $\mathrm{dM} 1+2$ length; br cell nearly as long as, but obviously narrower than, bm cell; discal cell nearly pentagonal, relatively short, about 

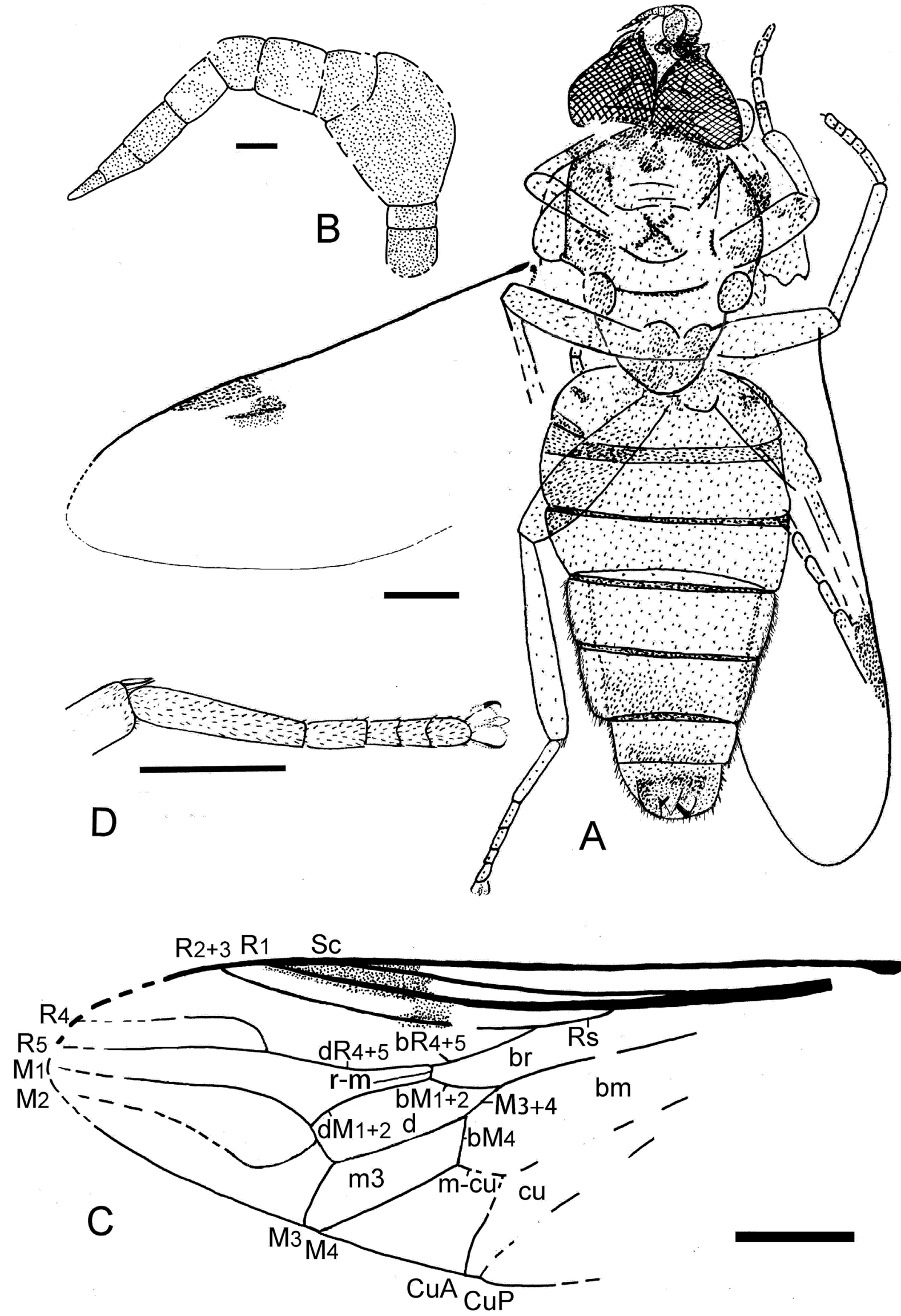

Figure 2. Sinonemestrius completus sp. n., no. NIGP L91803, line drawings of holotype. A habitus (wing venation omitted), B antenna, C left wing, D tarsus of left hindleg. Scale bars: $1 \mathrm{~mm}(\mathbf{A}, \mathbf{C}, \mathbf{D})$ and $0.1 \mathrm{~mm}(\mathbf{B})$. 

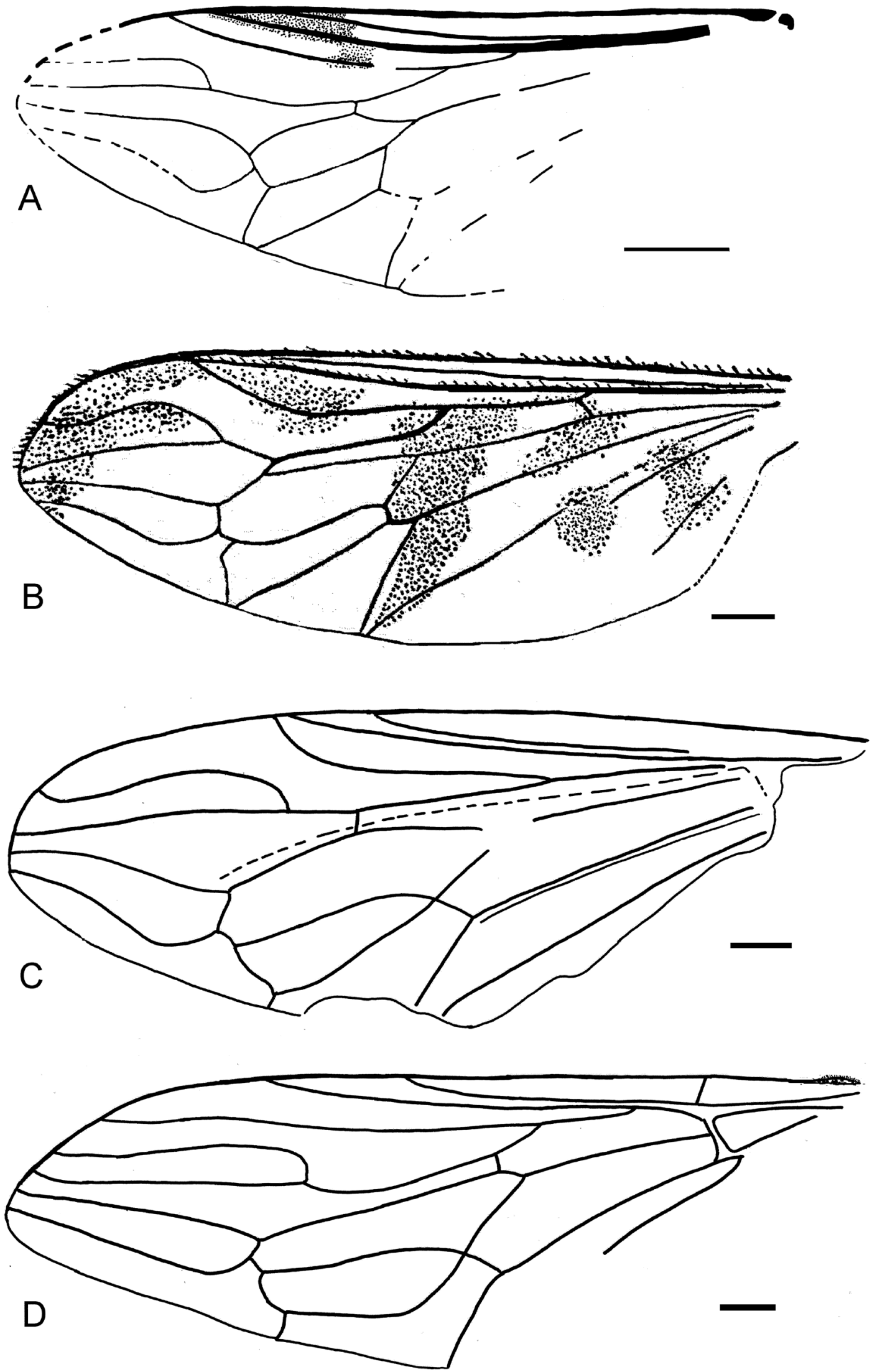

Figure 3. Difference and similarity between four sets of wings. Line drawings of holotypes. A Sinonemestrius completus sp. n., B Sinonemestrius tuanwangensis Hong \& Wang, 1990 (after Hong and Wang 1990), C Sinonemestrius akirai Jarzembowski \& Mostovski, 2000 (after Jarzembowski and Mostovski 2000), D Ahirmoneura neimengguensis K-y Zhang et al., 2008 (after K-y Zhang et al. 2008). Scale bars: $1 \mathrm{~mm}$. 
four times as long as wide; R4, R5, M1 and M2 slightly convergent, running towards wing tip (M1 ending just at wing tip); section of M3+4 slightly shorter than bM4; cell m3 nearly parallel quadrilateral but open apically; cell cu (traditionally anal cell) narrowly open. Legs with femora darkish brown, clavate, distinctly thicker than tibiae, tibiae and tarsi yellowish brown; femur of hindleg as long as, but twice as wide as, tibia, tibial spurs very short, distinctly less than tibial width, basitarsomere nearly as long as other tarsomeres combined, claw nearly as long as fifth tarsomere, empodium badly preserved, seemingly longer, but narrower, than pulvillus.

Abdomen ovate-oblong, with seven segments visible, clearly longer than head and thorax combined, with first segment longest, second segment widest, slightly wider than thorax; male genitalia longer than sixth segment with gonostylus (?) darkish brown, very narrow, strongly curved inwards.

Dimensions. Holotype: length of body $10.9 \mathrm{~mm}$; head, $1.4 \mathrm{~mm}$; thorax, $3.6 \mathrm{~mm}$; abdomen $6.4 \mathrm{~mm}$. Length of wing $7.4 \mathrm{~mm}$, width of wing $2.9 \mathrm{~mm}$.

Remarks. Sinonemestrius completus sp. n. differs from the type species Sinonemestrius tuanwangensis by the following features: R2+3 slightly curved, parallel to $\mathrm{R} 1$ and not meeting R1 end apically, fork of R4+5 distinctly distad to level of fork of $\mathrm{M} 1+2$, crossvein $\mathrm{r}-\mathrm{m}$ meeting anterior margin of $\mathrm{d}$ cell basad to its midlength and wing membrane with a few markings (only limited to "Pt" and below it). On the other hand, this new species differs from Sinonemestrius akirai by Rs arising from R stem late (at about one-third of wing length $v s$ near to wing base), the slightly curved $\mathrm{R} 2+3$ which runs parallel to R1 (vs R1 and R2+3 clearly convergent apically), fork of R4+5 distad ( $v s$ basad) to level of fork of M1+2 and cell $\mathrm{m} 3$ open ( $v s$ closed before hind margin of wing). Unfortunately, the body structures cannot be compared because the descriptions of the two known species are based on wing impressions.

Etymology. Latin, completus (complete), referring to the species erected based on a complete fly.

Holotype. No. NIGP L91803, a complete male fly, dorsoventral aspect, is held in the collection of NIGPAS.

Distribution. Type locality and horizon: Laiyang Formation, in the vicinity of Tuanwang, Laiyang, Shandong, China (Lower Cretaceous).

Repository. The Nanjing Institute of Geology and $\mathrm{Pa}$ laeontology, Chinese Academy of Sciences.

\section{Discussion}

On the basis of a single wing of a fly from the Lower Cretaceous of the Laiyang Formation, Shandong, China, Hong and Wang (1990) erected the monotypic genus Sinonemestrius, which was originally placed in Nemestrinidae. Nagatomi and Yang (1998) erected a new monobasic family Sinonemestriidae for this genus. They considered it to be the sister group of Nemestrinidae. Judging from another find of a wing from the Lower Cretaceous of southern
England, Jarzembowski and Mostovski (2000) described a new species referring it to Sinonemestrius and retained Sinonemestriidae only as a tribe within Heterostominae, Xylophagidae; also, the diagnosis of Sinonemestrius was revised. Shortly after this study, Mostovski and MartínezDelclòs (2000) transferred Heterostominae (including Sinonemestrine) into Rhagionemestriidae, another extinct family which is considered as a connecting link between Xylophagidae and Nemestrinidae. Nel (2010) agreed to the proposal (Mostovski and Martínez-Delclòs 2000) that Sinonemestrius belongs to Rhagionemestriidae. He moved the two modern genera (i.e. Heterostomus Bigot, 1857 and Exeretoneura Macquart, 1846) into Xylophagidae following Palmer and Yeates (2000) and Mostovski (2010 pers. comm.). Grimaldi (2016) also agreed with the placement proposed by Mostovski and Martínez-Delclòs (2000) that Sinonemestrius is a rhagionemestriid genus, but argued that Rhagionemestriidae is without question closely related to Acroceridae based on a distinct but very rare fly in late Cretaceous amber, while the modern genera Heterostomus and Exeretoneura appear to belong in the Tabanomorpha and Xylophagidae respectively, based on the studies of Coscarón et al. (2013) and Palmer and Yeates (2000).

The body structures and wing venation of Sinonemestrius completus sp. n. reveal that Sinonemestrius is very similar to the modern genus Heterostomus. This is based on the following synapomorphies: hemispherical head comprised mostly of the eyes; male holoptic; antennal flagellum with eight flagellomeres, stylus (or arista) absent; a pair of metatibial spurs present (although very small in Sinonemestrius completus sp. n.). In addition, there are close similarities in wing venation: wing membrane always with markings; $\mathrm{C}$ reaching wing tip, thinned behind wing tip; $\mathrm{R} 2+3$ ending close to R1 end; R4 sigmoidal; R5 aligned with stem of R4+5; R5 (or M1) ending at wing tip; crossvein r-m present; cell br very narrow, distinctly narrower than cell bm; discal cell usually narrow and long; cell m3 open (only closed in Sinonemestrius akirai); cell cu (traditionally anal cell) narrow and long (narrowly open in Sinonemestrius, closed in Heterostomus). For this reason, the proposal is supported here that Sinonemestrius could be related to heterostomid flies (Jarzembowski and Mostovski 2000, Mostovski and Martínez-Delclòs 2000). However, the placement of Heterostomus has been much debated. This genus includes only a single species, Heterostomus curvipalpis Bigot, 1857 from Chile. Lately, most works have classified it in Xylophagidae (Woodley 1989, Sinclair et al. 1994, Stuckenberg 2001, Kerr 2010); previously, it was included in various families within Tabanomorpha (Kröber 1930, Malloch 1932, Hennig 1972). Recently, the adult and pupa of Heterostomus curvipalpis were described and illustrated in detailed by Coscarón et al. (2013). They concluded that Heterostomus curvipalpis is related to Pelecorhynchidae within Tabanomorpha. Thus, it could be reasonable to retain Sinonemestriidae as a subfamily within Heterostomidae erected by Nagatomi (1977), and place these taxa in Tabanomorpha. 


\section{Acknowledgements}

I am deeply indebted to Dr M. B. Mostovski (The Steinhardt Museum of Natural History and Israel National Center for Biodiversity Studies, Department of Zoology, George S. Wise Faculty of Life Sciences, Tel Aviv University, Ramat Aviv, Israel and School of Life Sciences, University of KwaZulu-Natal, Scottsville, South Africa) and Dr A. Nel (Muséum National d'Histoire Naturelle, Entomologie, Paris, France) for critical remarks and improving the previous version of the manuscript. I also sincerely thank Visiting Prof. Dr E. A. Jarzembowski (NIGPAS and The Natural History Museum, London, UK) for suggesting edits to the English. The research was supported by the Nanjing Institute of Geology and Palaeontology, Chinese Academy of Sciences (Y421120502)

\section{References}

Bigot J (1857) Diptères nouveaux provenant du Chili. Annales de la Société Entomologique de France 5: 277-308.

Coscarón S, Coscarón MDC, Gil-Azevedo, LH (2013) On the enigmatic Heterostomus curvipalpis Bigot, 1857, with a description of the pupa (Diptera, Brachycera). Zootaxa 3616: 268-276. https://doi. org/10.11646/zootaxa.3616.3.4

Grimaldi DA (2016) Diverse orthorrhaphan flies (Insecta: Diptera: Brachycera) in amber from the Cretaceous of Myanmar: Brachycera in Cretaceous amber, Part VII. Bulletin of the American Museum of Natural History 408: 1-131. https://doi.org/10.1206/0003-0090-408.1.1

Hennig W (1972) Eine neue Art der Rhagionidengattung Litoleptis aus Chile, mit Bemerkungen über Fühlerbildung und Verwandtschaftsbeziehungen einiger Brachycerenfamilien (Diptera: Brachycera). Stuttgarter Beiträge zur Naturkunde 242: 1-18.

Hong Y-c, Wang W-1 (1988) Sinolestinae, an early Cretaceous new subfamily of Platypezidae (Insecta, Diptera) from the Laiyang Basin, Shandong Province. Geoscience 2: 386-392.

Hong Y-c, Wang W-1 (1990) Fossil insects from the Laiyang Basin, Shandong Province: 44-189. In: The Regional Geological Surveying Team (Eds) Stratigraphy and paleontology of the Laiyang Basin, Shandong. Geological Publishing House, Beijing, 255 pp.

Kerr PH (2010) Phylogeny and classification of Rhagionidae, with implications for Tabanomorpha (Diptera: Brachycera). Zootaxa 2592: $1-133$.

Jarzembowski EA, Mostovski MB (2000) A new species of Sinonemestrius (Diptera: Brachycera) from the Weald Clay (Lower Cretaceous, southern England), with a discussion of its affinities and stratigraphical implications. Cretaceous Research 21: 761-765. https://doi.org/10.1006/cres.2000.0226

Kröber O (1930) Tabanidae: 106-161. In: Edwards FW (Ed) Diptera of Patagonia and South Chile, Part 5. British Museum (Natural History), London, 293 pp.

Macquart J (1846) Diptères exotiques nouveaux ou peu connus. Mémoires de la Société (Royale) des Sciences, de l'Agriculture et des Arts á Lille (Supplement), Paris 1844: 133-364.

Malloch JR (1932) Rhagionidae, Therevidae: 199-257. In: Edwards FW (Ed.) Diptera of Patagonia and South Chile, Part 5. British Museum (Natural History), London, 293 pp.
Mostovski MB, Martínez-Delclòs X (2000) New Nemestrinoidea (Diptera: Brachycera) from the Upper Jurassic - Lower Cretaceous of Eurasia, taxonomy and palaeobiology. Entomological Problems 31: 137-148.

Nagatomi A (1977) Classification of lower Brachycera (Diptera). Journal of Natural History 11: 321-335. https://doi. org/10.1080/00222937700770231

Nagatomi A, Yang D (1998) A review of extinct Mesozoic genera and families of Brachycera (Insecta, Diptera, Orthorrhapha). Entomologist's Monthly Magazine 134: 95-192.

Nel A (2010) A new Mesozoic-aged rhagionemestriid fly (Diptera: Nemestrinoidea) from China. Zootaxa 2645: 45-54.

Palmer CM, Yeates DK (2000) Phylogenetic importance of immature stages: solving the riddle of Exeretonevra Macquart (Diptera: Xylophagidae). Annals of the Entomological Society of America 93: 15-27. https://doi.org/10.1603/0013-8746(2000)093[0015:PIOISS]2.0.CO;2

Ren D (1998) Late Jurassic Brachycera from northern China (Insecta: Diptera). Acta Zootaxonomica Sinica 23: 65-82.

Ren D, Guo Z-g (1995) A new genus and two new species of shorthorned flies of Upper Jurassic from northeast China (Diptera: Eremochaetidae). Entomologia Sinica 2: 300-307. https://doi. org/10.1111/j.1744-7917.1995.tb00051.x

Shcherbakov DE, Lukashevich ED, Blagoderov VA (1995) Triassic Diptera and initial radiation of the order. International Journal of Dipterological Research 6: 75-115.

Sinclair BJ, Cumming JM, Wood D (1994) Homology and phylogenetic implications of male genitalia in Diptera-Lower Brachycera. Entomologica Scandinavica 24: 407-432. https://doi. org/10.1163/187631293X00190

Stuckenberg BR (2001) Pruning the tree: a critical review of classifications of the Homeodactyla (Diptera, Brachycera) with new perspectives and an alternative classification. Studia Dipterologica 8: 3-41.

Woodley NE (1989) Phylogeny and classification of the "orthorrhaphous" Brachycera, Chapter 115: 1371-1395. In: McAlpine JF, Wood DM (Eds) Manual of Nearctic Diptera 3. Research Branch Agriculture Canada, Ottawa, 1581 pp.

Wootton RJ, Ennos AR (1989) The implications of function on the origin and homologies of the dipterous wing. Systematic Entomology 14: 507-520. https://doi.org/10.1111/j.1365-3113.1989.tb00300.x

Zhang J-f (1987) Four new genera of Platypezidae. Acta Palaeontologica Sinica 26: 595-603.

Zhang J-f (1992) The late Mesozoic entomofauna from Laiyang, Shandong Province, China, with discussion of its palaeoecological and stratigraphical significance. Cretaceous Research 13: 133-145. https://doi.org/10.1016/0195-6671(92)90031-K

Zhang J-f(2012) New horseflies and water snipe-flies (Diptera: Tabanidae and Athericidae) from the Lower Cretaceous of China. Cretaceous Research 36: 1-5. https://doi.org/10.1016/j.cretres.2012.01.004

Zhang J-f (2014) New male eremochaetid flies (Diptera, Brachycera, Eremochaetidae) from the Lower Cretaceous of China. Cretaceous Research 49: 205-213. https://doi.org/10.1016/j.cretres.2014.02.012

Zhang J-f (2015) Pseudapiocera shandongensis gen. et sp. nov., a protapiocerid fly (Diptera: Brachycera: Protapioceridae) from the Early Cretaceous Jehol biota, China. Alcheringa 39: 459-464. https://doi. org/10.1080/03115518.2015.1022335

Zhang J-f, Zhang S, Li L-y (1993) Mesozoic gadflies (Insecta: Diptera). Acta Palaeontologica Sinica 32: 662-672.

Zhang K-y, Yang D, Ren D, Ge F (2008) New Middle Jurassic tangleveined flies from Inner Mongolia, China. Acta Palaeontologica Polonica 53: 161-164. https://doi.org/10.4202/app.2008.0112 